\title{
Determination and Quantification of Vanadium(V) in Environmental Samples Using Chemically Modified Chitosan Sorbent
}

\author{
Tharakeswar Yadamari, Kalyan Yakkala, Ramakrishna Naidu Gurijala* \\ Department of Environmental Sciences, Sri Venkateswara University, Tirupati, India \\ Email: tharak15@gmail.com, kalyan.yk@gmail.com, ${ }^{*}$ naidugrk@gmail.com
}

Received 30 April 2014; revised 24 May 2014; accepted 24 June 2014

Copyright (C) 2014 by authors and Scientific Research Publishing Inc.

This work is licensed under the Creative Commons Attribution International License (CC BY). http://creativecommons.org/licenses/by/4.0/

(c) (i) Open Access

\section{Abstract}

The application of biopolymers such as chitosan is one of the emerging sorption methods for the removal of metal ions, even at low concentrations. A rapid, sensitive and selected method is described for preconcentrative determination of vanadium(V) using the synthesized 3-Hydroxybenzaldehyde-4 Amino antipyrine (HBAP), which was chemically immobilized on chitosan. This is easy to prepare in comparison to many other sorbents. The synthesized sorbent material was selective to vanadium(V) within a better response time of $30 \mathrm{~min}$. The method was selective in presence of other foreign ions like $\mathrm{Cl}^{-}, \mathrm{F}^{-}, \mathrm{SO}_{4}^{2-}, \mathrm{PO}_{4}^{3-}, \mathrm{Na}^{+}, \mathrm{Ca}^{2+}, \mathrm{Zn}^{2+}, \mathrm{Fe}^{3+}, \mathrm{Fe}^{2+}, \mathrm{Cu}^{2+}, \mathrm{Cr}^{3+}, \mathrm{EDTA}$, $\mathrm{Mn}^{2+}, \mathrm{Co}^{2+}$ and $\mathrm{Ni}^{2+}$. The calibration plots were linear over the concentration range of $0.5 \mu \mathrm{g} \cdot \mathrm{L}^{-1}$ to $7 \mu \mathrm{g} \cdot \mathrm{L}^{-1}$ of vanadium(V). These values are 100 times lower than by the direct determination of vanadium by FAAS. The developed procedure was reproducible with a relative standard deviation of $\mathbf{2 . 8 4} \%$. The developed sorbent was successfully applied for the determination of vanadium(V) in real water and soil samples. Unlike most preconcentration procedures, the present enrichment method allowed for a rapid and reliable determination of vanadium( $V$ ) in environmental samples by the simple and routinely available flame atomic absorption spectrometry technique.

\section{Keywords}

Vanadium(V), Chitosan, Preconcentration, FAAS, Environmental Samples

\section{Introduction}

Vanadium compounds are released in large quantities from burning fossil fuels and from various industrial

"Corresponding author.

How to cite this paper: Yadamari, T., Yakkala, K. and Gurijala, R.N. (2014) Determination and Quantification of Vanadium(V) in Environmental Samples Using Chemically Modified Chitosan Sorbent. Journal of Encapsulation and Adsorption Sciences, 4, 53-61. http://dx.doi.org/10.4236/jeas.2014.42006 
processes [1]. These are precipitated on the soil drained by rain and groundwater and directly adsorbed by plants, animals and humans. Vanadium content in food is directly dependent upon the concentrations present in the soil. Whereas, the concentration of vanadium in water is largely dependent on geographical location and ranges from 0.2 to $>100 \mu \mathrm{g} \cdot \mathrm{L}^{-1}$ in fresh water and drinking water, from 0.2 to $29 \mu \mathrm{g} \cdot \mathrm{L}^{-1}$ in seawater and the typical values lies between 1 and $6 \mu \mathrm{g} \cdot \mathrm{L}^{-1}$ [2]-[4]. The toxicity of vanadium is dependent on its oxidation state, with vana$\operatorname{dium}(\mathrm{V})$ being more toxic than vanadium (IV) and its poisoning symptoms are sometimes fatal [5]. Industrial discharges in application of vanadium such as dyeing, ceramics, ink and catalyst manufacturers contribute to its presence in water supply [6]. Vanadium in soils at concentrations of $10 \mathrm{mg} \cdot \mathrm{kg}^{-1}$ or more is toxic for terrestrial plants [7]. The threshold limit values (TLV) reported are $0.5 \mathrm{mg} / \mathrm{cubic}$ meter of air and $0.1 \mathrm{mg} / \mathrm{cubic}$ meter of fume [8]. Therefore, the determination of vanadium in environmental samples is necessary in terms of environmental protection. Several analytical techniques have been reported for the determination of vanadium, which include spectrophotometry [9]-[15], neutron activation analysis (NAA) [16] [17], inductively coupled plasma mass spectrometry (ICP-MS) [18], inductively coupled plasma optical emission spectrometry (ICP-OES) [1] [19], atomic absorption spectrometry [20] [21], in various environmental samples. However, most of these techniques suffer from several setbacks such as, multiple spectral interferences in spectrophotometric methods, few techniques like ICP-MS and ICP-OES are expensive, NAA method is time-consuming and requires sophisticated instrumentation and atomic absorption spectrometric (AAS) determinations are either insensitive (flame) or non selective due to pronounced matrix interference (graphite furnace). The direct analysis of vanadium in complex matrices is difficult as they occur at very low concentrations. In order to achieve accurate and sensitive results, a suitable preconcentration step is required to address these problems in the analysis of real samples.

The use of chitosan to treat low concentration of heavy metals from environmental samples has grown recently because of its high adsorptive capacity when compared to other adsorbents [22].

In this work, a rapid sensitive and selected method is described for preconcentrative determination of vanadium(V) using the synthesized 3-Hydroxybenzaldehyde-4 Amino antipyrine, which was chemically immobilized on chitosan.

\section{Materials and Methods}

\subsection{Chemicals and Reagents}

All the reagents used in this study were of analytical grade and standard solutions of vanadium(V) were prepared by dissolving appropriate amounts of ammonium metavanadate $(99.99 \%$, Merck) in double distilled water. The $0.1 \mathrm{~mol} \cdot \mathrm{L}^{-1}$ acetic acid/acetate buffer solution was prepared by adjusting the $\mathrm{pH}$ to 3.5 . Commercially available chitosan was used for the present study.

\subsection{Synthesis of 3-Hydroxybenzaldehyde-4-Amino Antipyrine}

The 3-Hydroxybenzaldehyde-4-Amino antipyrine was synthesized by refluxing equimolar amount of 3-Hydroxybenzaldehyde (99\%, Merck) and 4 Amino antipyrine (99\%, Merck) in methanol for 3 hours at $40^{\circ} \mathrm{C}$ [23]. The product was recrystallized from each solvent used in the synthesis and dried at room temperature. The product (HBAP) was characterized by infrared spectroscopy using $\mathrm{KBr}$ pellet method.

About 1.6268 grams of 3-Hydroxybenzaldehyde-4-Amino antipyrine synthesized product was dissolved in Dimethylformamide in $100 \mathrm{~mL}$ volumetric flask, from this a known volume of $0.05 \mathrm{~mol} \cdot \mathrm{L}^{-1} \mathrm{HBAP}$ was used for the determination of vanadium(V).

\subsection{General Procedure}

To the known concentration of vanadium(V), standard solutions were adjusted to $\mathrm{pH}=3.5 \pm 0.2$ by adding $3 \mathrm{~mL}$ of acetic acid acetate buffer. An amount of $30 \mathrm{mg}$ of chitosan and $0.5 \mathrm{ml}$ of synthesized $0.05 \mathrm{~mol} \cdot \mathrm{L}^{-1} 3-\mathrm{Hy}-$ droxybenzaldehyde-4-Amino antipyrine was added to the above solution and stirred for about 30 minutes and the solution was filtered by using vacuum filtration. The filtered solution was eluted with $20 \mathrm{ml}$ of $1 \mathrm{~mol} \cdot \mathrm{L}^{-1}$ $\mathrm{HCl}$ solution and then the vanadium is determined by Flame atomic absorption spectrometer (FAAS).

\subsection{Apparatus}

Measurements were performed with a model 6300 Flame atomic absorption spectrometer (FAAS), Shimadzu 
(Japan), with flame of $\mathrm{N}_{2} \mathrm{O}-\mathrm{C}_{2} \mathrm{H}_{2}$ and the instrument settings were according to the manufacturer's recommendations. A LI-120 digital $\mathrm{pH}$ meter (Elico, India) was used for the $\mathrm{pH}$ measurement and reagents and chemicals were weighed using analytical balance, Shimadzu AUX 320.

UV-visible spectrophotometer model UV-1800 from Shimadzu (Japan), was used for recording the absorbance spectra for the complexation studies of vanadium(V). IR spectrometer (Thermo-Nicolet FT-IR, Nicolet IR-200, USA) was used for the analysis of functional groups in the synthesized reagent.

\subsection{Procedure for Soil Analysis}

Soil samples were collected in and around industrial sites of Tirupati. The collected soil samples were air dried at $70^{\circ} \mathrm{C}$ in the laboratory oven and then grinded to fine powder and then sieved through $0.25 \mathrm{~mm}$ nylon mesh. To one gram of soil sample, $8 \mathrm{~mL}$ concentrated $\mathrm{HCl}$ and $2 \mathrm{~mL}$ concentrated $\mathrm{HNO}_{3}$ were added and kept for overnight [24]. After digestion and filtration, the solution was subjected to separation by following the general procedure described above and subjected to FAAS for determination of vanadium(V).

\subsection{Application to Real Samples}

The developed procedure was used for the quantification and determination of $\mathrm{V}(\mathrm{V})$ ions in the real water and soil samples. The water and soil samples were collected in and around industrial sites of Tirupati. To the $20 \mathrm{~mL}$ of water sample (ground water/tap water) and acid digested soil sample followed by the general procedure described above and finally subjected to FAAS for the determination of vanadium(V).

\subsection{Interference Study}

The interference of foreign ions like $\mathrm{Cl}^{-}, \mathrm{F}^{-}, \mathrm{SO}_{4}^{2-}, \mathrm{PO}_{4}^{3-}, \mathrm{Na}^{+}, \mathrm{Ca}^{2+}, \mathrm{Zn}^{2+}, \mathrm{Fe}^{3+}, \mathrm{Fe}^{2+}, \mathrm{Cu}^{2+}, \mathrm{Cr}^{3+}, \mathrm{EDTA}, \mathrm{Mn}^{2+}$, $\mathrm{Co}^{2+}$ and $\mathrm{Ni}^{2+}$ was studied by equilibrating the fixed amount of vanadium( $(\mathrm{V})$ along with the reagent sorbent solution at $\mathrm{pH}=3.5$ and later the determinations was made by FAAS.

\section{Results and Discussion}

\subsection{Characterization of Developed Sorbent}

The synthesized reagent 3-Hydroxybenzaldehyde-4-Amino antipyrine (HBAP) immobilized on the surface of chitosan was found to complex with vanadium(V) ions at $\mathrm{pH}=3.5$. This metal complexation with HBAP is due to its phenolic rings leaving the hydrophilic moieties (oxygen and azo-nitrogens) that are available for metal complexation through the formation of one or two coordination spheres leading to the respective stable structure. This seems to suggest that terdentate ligand (HBAP) is assumed to form 1:2 metal-HBAP complex in the developed preconcentration step as shown in Scheme 1.

The FTIR spectra of 3-Hydroxybenzaldehyde-4-Amino antipyrine (HBAP) were recorded and are shown in Figure 1. Here the vibration bands at $3424.30 \mathrm{~cm}^{-1}, 1630.41 \mathrm{~cm}^{-1}, 2919.44 \mathrm{~cm}^{-1}$ and $1517.17 \mathrm{~cm}^{-1}$ are due to the presence of hydroxyl group, Carbonyl $(\mathrm{C}=\mathrm{O}), \mathrm{C}-\mathrm{H}$ and presence $\mathrm{C}-\mathrm{N}$ stretching vibrations respectively.

The reaction of HBAP solution with vanadium(V) cation forms a pink colour with a maximum absorbance at $525 \mathrm{~nm}$ as shown in Figure 2. The blank HBAP reagent has an absorption maximum at $383 \mathrm{~nm}$, whereas the HBAP-vanadium(V) complex reaches a maximum after $10 \mathrm{~min}$ and this is stable for at least $2 \mathrm{~h}$.

\subsection{Experimental Optimum Conditions}

The uptake efficiency of $5 \mu \mathrm{g} \cdot \mathrm{L}^{-1}$ vanadium(V) in $20 \mathrm{~mL}$ of HBAP solution was studied as a function of $\mathrm{pH}$. As seen from the Figure 3, the decrease in percentage enrichment at $\mathrm{pH}$ less than 3.0 and above 4.0 is due to the insufficient formation of the vanadium(V)-HBAP complex. Thus, the optimum $\mathrm{pH}=3.5$ was selected throughout the experiment by adjusting the $\mathrm{pH}$ using acetic acid acetate buffer.

To know the optimum reagent concentration, $0.05 \mathrm{~mol} \cdot \mathrm{L}^{-1} \mathrm{HBAP}$ reagent solution prepared using dimethylfarmamide ranging $0.3 \mathrm{~mL}$ to $1 \mathrm{~mL}$ was used to know the optimum reagent concentration. Absorbance increases with increase of volume of HBAP reagent up to $0.4 \mathrm{~mL}$ and thereafter it remains constant. Hence further studies were carried out using $0.5 \mathrm{~mL}$ of HBAP reagent. The weight of chitosan sorbent was tested ranging from $10 \mathrm{mg}$ to $50 \mathrm{mg}$ and found that $30 \mathrm{mg}$ of sorbent was sufficient for the effective preconcentration of vanadium(V). 


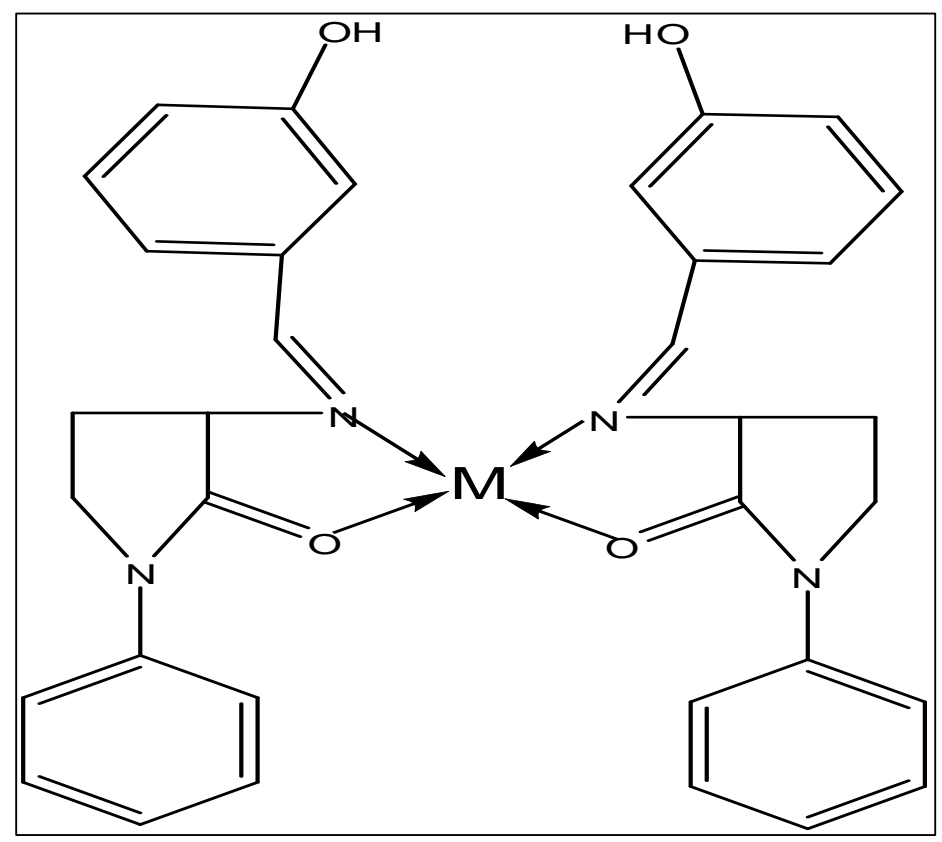

$\mathrm{M}=\operatorname{vanadium}(\mathrm{V})$

Scheme 1. Chemical structure of metal-HBAP complex in 1:2 ratio.

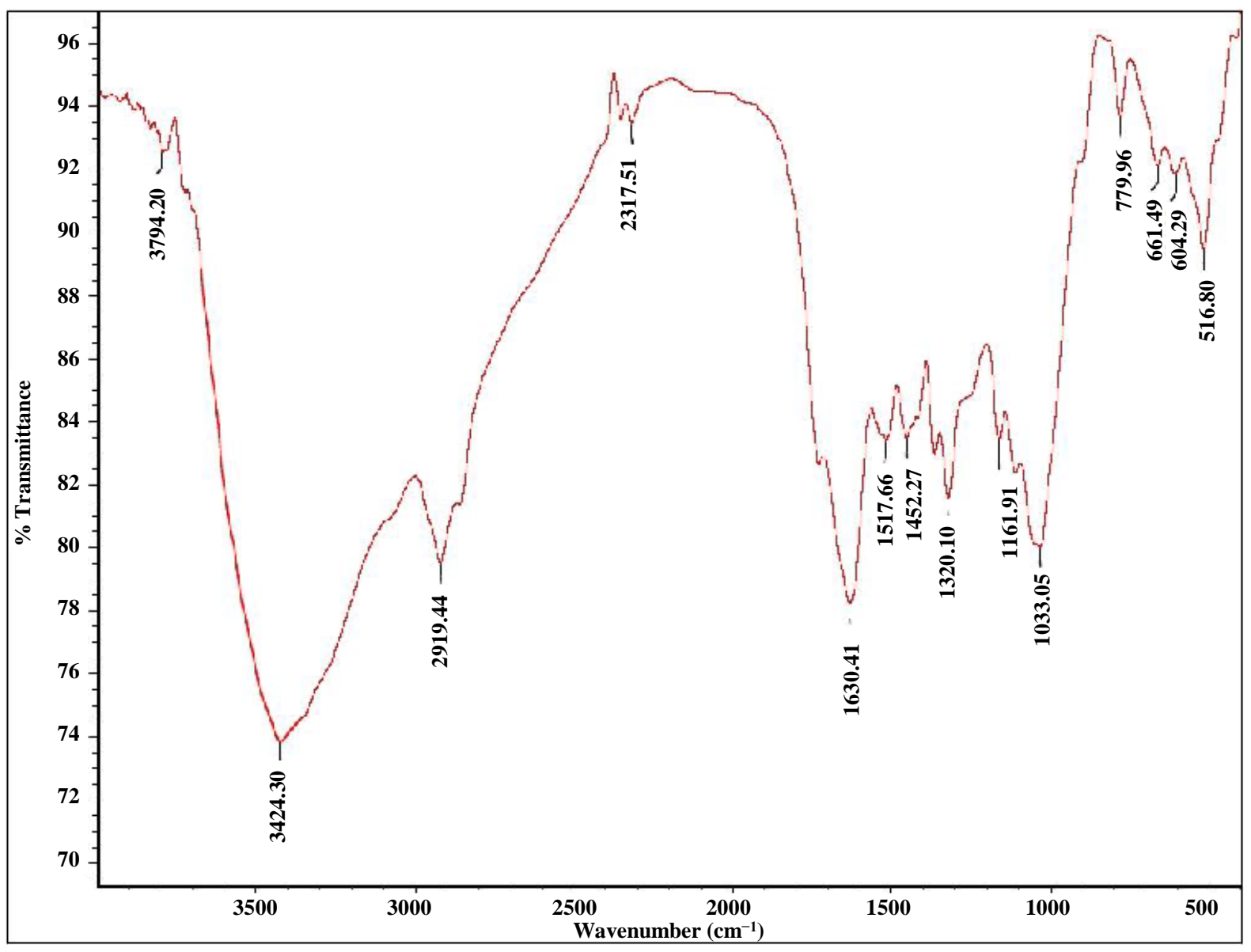

Figure 1. FTIR spectrum of the synthesized 3-Hydroxybenzaldehyde-4 Amino antipyrine (HBAP) reagent. 


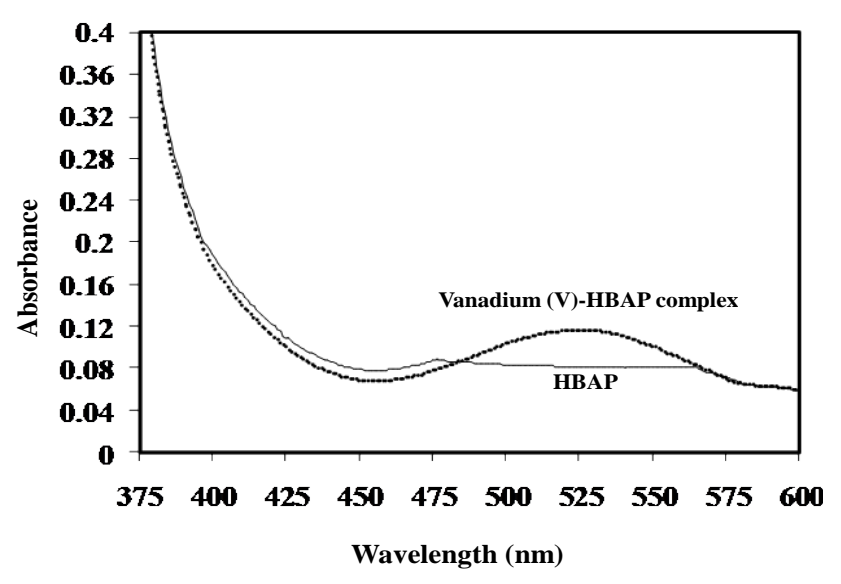

Figure 2. Absorption spectra of HBAP and its vanadium(V) complex.

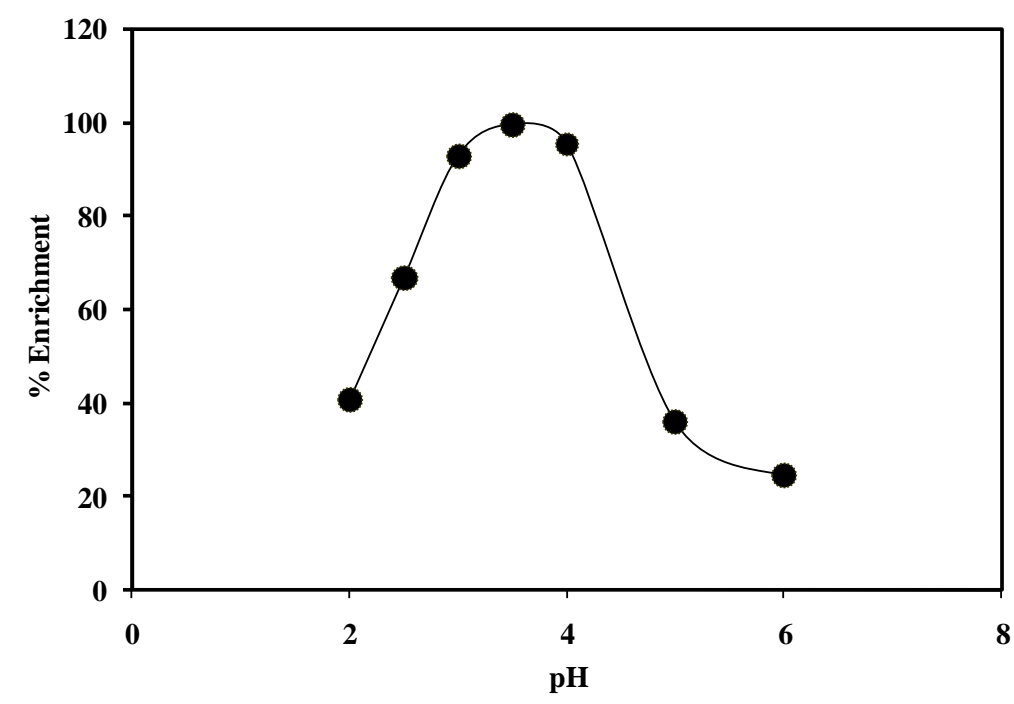

Figure 3. \% enrichment of vanadium(V) as a function of $\mathrm{pH}$ in fixed amount of $5 \mu \mathrm{g} \cdot \mathrm{L}^{-1}$ of vanadium(V).

Various reagents such as $1 \mathrm{~mol} \cdot \mathrm{L}^{-1} \mathrm{HCl}, 1 \mathrm{~mol} \cdot \mathrm{L}^{-1} \mathrm{HNO}_{3}$ and $1 \mathrm{~mol} \cdot \mathrm{L}^{-1} \mathrm{H}_{2} \mathrm{SO}_{4}$ were tested for eluting the complexed vanadium(V) for its determination by FAAS. It was found that $20 \mathrm{~mL}$ of $1 \mathrm{~mol} \cdot \mathrm{L}^{-1} \mathrm{HCl}$ could effectively elute vanadium(V) from the HBAP chitosan sorbent. The equilibration time required for the better enrichment of vanadium(V) was found to be $30 \mathrm{~min}$. The optimization conditions of preconcentration of vanadium(V) were shown in Table 1.

\subsection{FAAS Analysis and Its Analytical Performance}

It was observed from FAAS analysis, that the response of the eluted vanadium(V) from equilibrated HBAP chitosan sorbent was linear in the concentration range of $0.5 \mu \mathrm{g} \cdot \mathrm{L}^{-1}-7 \mu \mathrm{g} \cdot \mathrm{L}^{-1}$ vanadium(V) as shown in Figure 4 with a detection limit of $0.1 \mu \mathrm{g} \cdot \mathrm{L}^{-1}$. These values are 100 times lower than by direct flame atomic absorption spectrometry (FAAS) method after preconcentration with HBAP chitosan sorbent. The precision of the developed procedure is considered good with a relative standard deviation of $2.84 \%$. The unknown vanadium within this range can be quantified from the calibration graph obtained.

\subsection{Interference Studies and Application to Real Samples}

In order to study the selectivity, the HBAP chitosan sorbent was equilibrated with a fixed amount of 0.01 
Table 1. Optimization of experimental parameters during preconcentration and elution of $5 \mu \mathrm{g} \cdot \mathrm{L}^{-1}$ of vanadium(V).

\begin{tabular}{|c|c|c|c|}
\hline S.No & Experimental Parameter & \% Enrichment & Chosen condition \\
\hline \multirow[t]{5}{*}{1} & Weight of the sorbent (mg) & & $30 \mathrm{mg}$ \\
\hline & $10 \mathrm{mg}$ & 78.57 & \\
\hline & $20 \mathrm{mg}$ & 86.36 & \\
\hline & $30 \mathrm{mg}$ & 99.99 & \\
\hline & $50 \mathrm{mg}$ & 99.99 & \\
\hline \multirow[t]{5}{*}{2} & Preconcentration time (min) & & $30 \mathrm{~min}$ \\
\hline & $5 \mathrm{~min}$ & 73.8 & \\
\hline & $15 \mathrm{~min}$ & 80.92 & \\
\hline & $30 \mathrm{~min}$ & 99.99 & \\
\hline & $45 \mathrm{~min}$ & 99.99 & \\
\hline \multirow[t]{4}{*}{3} & Eluting agent & & $1 \mathrm{~mol} \cdot \mathrm{L}^{-1} \mathrm{HCl}$ \\
\hline & $1 \mathrm{~mol} \cdot \mathrm{L}^{-1} \mathrm{HCl}$ & 100 & \\
\hline & $1 \mathrm{~mol} \cdot \mathrm{L}^{-1} \mathrm{HNO}_{3}$ & 85.71 & \\
\hline & $1 \mathrm{~mol} \cdot \mathrm{L}^{-1} \mathrm{H}_{2} \mathrm{SO}_{4}$ & 83.33 & \\
\hline \multirow[t]{4}{*}{4} & Volume of reagent (mL) & & $0.5 \mathrm{~mL}$ \\
\hline & $0.3 \mathrm{~mL}$ & 97.61 & \\
\hline & $0.5 \mathrm{~mL}$ & 99.99 & \\
\hline & $0.7 \mathrm{~mL}$ & 99.99 & \\
\hline \multirow[t]{4}{*}{5} & Volume of acetic acid buffer (mL) & & $1 \mathrm{~mL}$ \\
\hline & $1 \mathrm{~mL}$ & 92.85 & \\
\hline & $3 \mathrm{~mL}$ & 99.99 & \\
\hline & $5 \mathrm{~mL}$ & 99.99 & \\
\hline
\end{tabular}

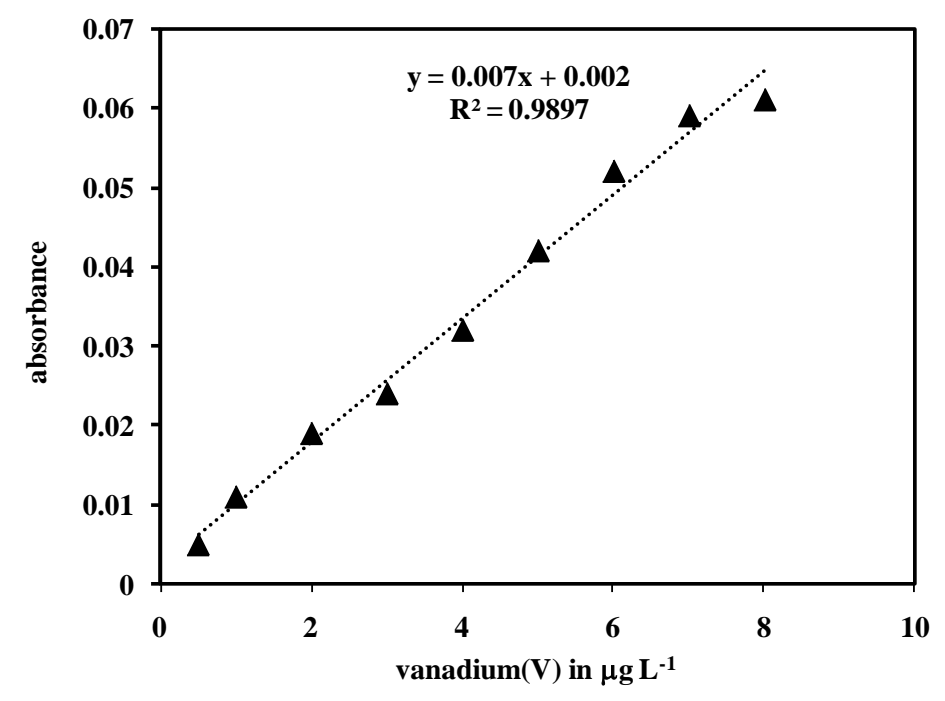

Figure 4. Calibration curve obtained from measurement of absorbance of eluted vanadium(V) by flame atomic absorption spectrophotometry. 
$\mathrm{mol} \cdot \mathrm{L}^{-1}$ vanadium $(\mathrm{V})$ and with increasing amounts of ions namely $\mathrm{Cl}^{-}, \mathrm{F}^{-}, \mathrm{SO}_{4}^{2-}, \mathrm{PO}_{4}^{3-}, \mathrm{Na}^{+}, \mathrm{Ca}^{2+}, \mathrm{Zn}^{2+}, \mathrm{Fe}^{3+}$, $\mathrm{Fe}^{2+}, \mathrm{Cu}^{2+}, \mathrm{Cr}^{3+}$, EDTA, $\mathrm{Mn}^{2+}, \mathrm{Co}^{2+}$ and $\mathrm{Ni}^{2+}$ at $\mathrm{pH}=3.5$. The absorbance of the eluted sample from the HBAP chitosan sorbent, which was equilibrated with solution containing interfering ions and vanadium(V) was compared with the absorbance of eluted sample from the HBAP chitosan sorbent, which was equilibrated in the absence of interfering ion with the solution having the same amount of vanadium under similar experimental conditions using FAAS. The tolerance limit of foreign ions in the determination of $0.01 \mathrm{~mol} \cdot \mathrm{L}^{-1}$ vanadium $(\mathrm{V})$ was summarized in Table 2.

The applicability of the developed sorbent was examined by spiking $2 \mu \mathrm{g} \cdot \mathrm{L}^{-1}$ of vanadium(V) in different ground waters and $2 \mu \mathrm{g} \cdot \mathrm{g}^{-1}$ of vanadium(V) in soil samples and the preconcentrated vanadium(V) was determined by FAAS. The recovery obtained in the range 97.5 to 102.5 as shown in Table 3(a) and Table 3(b), seems to suggest that the developed sorbent is feasible for real sample analysis.

\section{Conclusion}

HBAP immobilized chitosan sorbent was prepared and used as a potential sorbent for preconcentration and separation of vanadium(V) prior to their determination. The complexation of vanadium(V) in HBAP chitosan sorbent was studied as a function of $\mathrm{pH}$ and found that the efficiency was $100 \%$ at $\mathrm{pH}=3.5$. The equilibration time required for the better enrichment of vanadium $(\mathrm{V})$ was found to be $30 \mathrm{~min}$ and the complexed vanadium can be successfully eluted using $20 \mathrm{~mL}$ of $1 \mathrm{~mol} \cdot \mathrm{L}^{-1} \mathrm{HCl}$ for FAAS analysis. The calibration plots were linear over the concentration range of 0.5 to $7 \mu \mathrm{g} \cdot \mathrm{L}^{-1}$ vanadium(V). From the study of selectivity of the developed sorbent, it was found that vanadium $(\mathrm{V})$ can be preconcentrated from complex aqueous medium in presence of other ions like $\mathrm{Cl}^{-}, \mathrm{F}^{-}, \mathrm{SO}_{4}^{2-}, \mathrm{PO}_{4}^{3-}, \mathrm{Na}^{+}, \mathrm{Ca}^{2+}, \mathrm{Zn}^{2+}, \mathrm{Fe}^{3+}, \mathrm{Fe}^{2+}, \mathrm{Cu}^{2+}, \mathrm{Cr}^{3+}, \mathrm{EDTA}, \mathrm{Mn}^{2+}, \mathrm{Co}^{2+}$ and $\mathrm{Ni}^{2+}$ at $\mathrm{pH}=3.5$. The preconcentration of vanadium(V) ions from soil and water samples indicated the possibility of using the HBAP chitosan sorbent investigated in the present work for real samples.

\section{Acknowledgements}

The author G.R.K. Naidu thanks UGC, New Delhi, India for financial assistance of the project under UGC-BSR

Table 2. Tolerance limit of ions in the determination of $0.01 \mathrm{~mol} \cdot \mathrm{L}^{-1}$ vanadium $(\mathrm{V})$ in aqueous sample at $\mathrm{pH}=3.5$.

\begin{tabular}{ccc}
\hline S.No & Foreign ions & Tolerance [interference/vanadium(V)] \\
\hline 1 & $\mathrm{Cl}^{-}, \mathrm{F}^{-}$ & 15 \\
2 & $\mathrm{SO}_{4}^{2-}, \mathrm{PO}_{4}^{3-}$ & 10 \\
3 & $\mathrm{Na}^{+}, \mathrm{Ca}^{2+}, \mathrm{Zn}^{2+}, \mathrm{Fe}^{3+}, \mathrm{Fe}^{2+}, \mathrm{Cu}^{2+}$ & 8 \\
4 & $\mathrm{Cr}^{3+}, \mathrm{EDTA}^{2+}$ & 5 \\
5 & $\mathrm{Mn}^{2+}, \mathrm{Co}^{2+}, \mathrm{Ni}^{2+}$ & 4 \\
\hline
\end{tabular}

Table 3. (a) Determination of vanadium(V) in soil samples; (b) Determination of vanadium(V) in water samples.

(a)

\begin{tabular}{ccccc}
\hline S.No & Soil samples & vanadium added $\left(\mathrm{mg} \cdot \mathrm{g}^{-1}\right)$ & vanadium found $\left(\mathrm{mg} \cdot \mathrm{g}^{-1}\right)$ & \% recovery \\
\hline 1 & Soil sample-1 & 2 & $2.05 \pm 0.41$ & $102.5 \pm 2$ \\
2 & Soil sample-2 & 2 & $2.02 \pm 0.32$ & $101.0 \pm 2$ \\
3 & Soil sample-3 & 2 & $1.95 \pm 0.55$ & $97.5 \pm 2$ \\
\hline
\end{tabular}

(b)

\begin{tabular}{ccccc}
\hline S.No & Water samples & vanadium added $\left(\mu \mathrm{g} \cdot \mathrm{L}^{-1}\right)$ & vanadium found $\left(\mu \mathrm{g} \cdot \mathrm{L}^{-1}\right)$ & $\%$ recovery \\
\hline 1 & Water sample-1 & 2 & $2.02 \pm 0.24$ & $101.0 \pm 2$ \\
2 & Water sample-2 & 2 & $2.01 \pm 0.48$ & $100.5 \pm 2$ \\
3 & Water sample-3 & 2 & $2.00 \pm 0.55$ & $100.0 \pm 2$ \\
\hline
\end{tabular}


Faculty Fellowship grant.

\section{References}

[1] Wuilloud, R.G., Salonia, J.A., Olsina, R.A. and Martinez, L.D. (2000) Determination of Vanadium(V) in Drinking Water by Flow Injection and Preconcentration in a Knotted Reactor by Inductively Coupled Plasma Optical Emission Spectrometry with Ultrasonic Nebulization. Spectrochimica Acta Part B, 55, 671-680. http://dx.doi.org/10.1016/S0584-8547(00)00215-9

[2] Committee on Biologic Effects of Atmospheric Pollutants (1974) Vanadium. National Academy of Sciences, Washington DC.

[3] Waters, M.D. (1977) Toxicology of Vanadium. In: Goyer, R.A. and Mehlman, M.A., Ed., Advances in Modern Toxicology, Toxicology of Trace Elements, Wiley, New York, 147-189.

[4] Davies, D.J.A. and Bennett, B.G. (1983) Exposure Commitment Assessments of Environmental Pollutants. Vol. 3, Monitoring Assessment and Research Centre (MARC Report No. 30), University of London, London.

[5] Venugopal, B. and Luckey, T.D. (1979) Metal Toxicity in Mammals. Plenum Press, New York, 220.

[6] APHA (1995) Standard Methods for the Examination of Water and Wastewater. 19th Edition, American Public Health Association, Washington DC, 3-101.

[7] Arnon, D.I. (1958) The Role of Micronutrients in Plant Nutrition with Special Reference to Photosynthesis and Nitrogen Assimilation. In: Lamb, C.A., Bentley, O.G. and Beattie, O.G., Eds., Trace Elements, Academic Press, New York, $1-32$.

[8] Kolthoff, I.M., Elving, P.I. and Stross, F.H. (1971) Treatise on Analytical Chemistry, Part III. Wiley Interscience, New York, 89.

[9] Kiriyana, T. and Kuroda, R. (1972) A Combined Ion-Exchange Spectrophotometric Determination of Vanadium in Sea and Natural Waters. Analytica Chimica Acta, 62, 464-467. http://dx.doi.org/10.1016/0003-2670(72)80060-6

[10] Kiran Kumar, T.N. and Revanasiddappa, H.D. (2005) Spectrophotometric Determination of Vanadium Using Variamine Blue and Its Application to Synthetic, Environmental and Biological Samples. Journal of the Iranian Chemical Society, 2, 161-167.

[11] Rostampour, L. and Ali Tahar, M. (2008) Determination of Trace Amounts of Vanadium By UV-Vis Spectrophotometric after Separation and Preconcentration with Modified Natural Clinoptilolite as a New Sorbent. Talanta, 75, 12791283. http://dx.doi.org/10.1016/j.talanta.2008.01.045

[12] Amin, A.S. (2003) Solid-Phase Spectrophotometric Determination of Trace Amounts of Vanadium Using 2,3-Dichloro-6(3-carboxy-2-hydroxynaphthylazo) quinoxaline. Spectrochemica Acta Part A, 59, 1025-1033. http://dx.doi.org/10.1016/S1386-1425(02)00259-7

[13] Mahaveer, B.M., Jaldappa, S. and Saraswati, P.M. (2001) Spectrophotometric Determination of Vanadium(V) in Minerals, Steels, Soil and Biological Samples Using Phenothiazine Derivatives. Analytical Sciences, 17, 979-982. http://dx.doi.org/10.2116/analsci.17.979

[14] Hu, Q., Yang, G., Huang, Z. and Yin, J. (2004) Study on Solid Phase Extraction and Spectrophotometric Determination of Vanadium with 2-(2-Quinolylazo)-5-Diethylaminophenol. Bulletin of the. Korean Chemical Society, 25, 263266. http://dx.doi.org/10.5012/bkcs.2004.25.2.263

[15] Agnihotri, N., Dass, R. and Mehta, J.R. (1999) A Highly Sensitive and Selective Spectrophotometric Determination of Vanadium(V) Using 6-Chloro-3-hydroxy-7-methyl-2-(2-thienyl)-4H-chromen-4-one. Analytical Science, 15, 12611264. http://dx.doi.org/10.2116/analsci.15.1261

[16] Murthy, R.S.S. and Ryan, D.E. (1983) Determination of Arsenic Molybdenum, Uranium and Vanadium in Sea-Water by Colloid Flotation. Analytical Chemistry, 55, 682-684. http://dx.doi.org/10.1021/ac00255a023

[17] Greenberg, R.R. and Kingston, H.M. (1983) Trace Element Analysis of Natural Water Samples by Neutron Activation Analysis with Chelating Resin. Analytical Chemistry, 55, 1160-1165. http://dx.doi.org/10.1021/ac00258a041

[18] Sabbioni, E., Kueera, J., Pietra, R. and Vesterberg, O. (1996) A Critical Review on Normal Concentration of Vanadium in Human Blood, Serum, and Uranine. Science Total Environment, 188, 49-58. http://dx.doi.org/10.1016/0048-9697(96)05164-9

[19] Hirata, S., Umezaki, Y. and Ikeda, M. (1986) Determination of Chromium (III), Titanium, Vanadium, Iron (III) and Aluminum by Inductively Coupled Plasma Atomic Emission Spectrometry with an On-Line Preconcentration IonExchange Column. Analytical Chemistry, 58, 2602-2606. http://dx.doi.org/10.1016/0048-9697(96)05164-9

[20] Wu, W., Qian, S.-H., Xiao, M., Huang, G.-Q. and Chen, H. (2002) Preconcentration of Vanadium(V) on Cross Linked Chitosan and Determination by Graphite Furnace Atomic Absorption Spectrometry. Wuhan University Journal of Natural Science, 7, 222-226. http://dx.doi.org/10.1007/BF02830323 
[21] Yanashige, T., Yananoto, M. and Sunahara, H. (1989) Comparison of Decomposition Methods for the Analysis of Atmospheric Particulates by Atomic Absorption Spectrometry. Analyst, 114, 1071-1077. http://dx.doi.org/10.1039/an9891401071

[22] Osifo, P.O., Neomgus, H.W.J.P., Everson, R.C., Webster, A., and Gun, M. (2009) The Adsorption of Copper in a Packed-Bed of Chitosan Beads: Modeling Multiple Adsorption and Regeneration. Journal of Hazardous Materials, 167, 1242-1245. http://dx.doi.org/10.1016/j.jhazmat.2009.01.109

[23] Park, C.I., Kim, H.S. and Cha, K.W. (1999) Spectrophotometric Determination of Copper after Selective Extraction with $\alpha$-(2-Benzimidazolyl)- $\alpha$ ', $\alpha$ "-(N-5-nitro-2-Pyridyl hydrazone)-toluene in the Presence of Brij 58. Bulletin of the Korean Chemical Society, 20, 352-354.

[24] McGrath, S.P. and Cunliffe, C.H. (1985) A Simplified Method for the Extraction of the Metals Fe, Zn, Cu, Ni, Cd, Pb, $\mathrm{Cr}, \mathrm{Co}$ and Mn from Soils and Sewage Sludge. Journal of the Science of Food and Agriculture, 36, 794-798. http://dx.doi.org/10.1002/jsfa.2740360906 
Scientific Research Publishing (SCIRP) is one of the largest Open Access journal publishers. It is currently publishing more than 200 open access, online, peer-reviewed journals covering a wide range of academic disciplines. SCIRP serves the worldwide academic communities and contributes to the progress and application of science with its publication.

Other selected journals from SCIRP are listed as below. Submit your manuscript to us via either submit@scirp.org or Online Submission Portal.
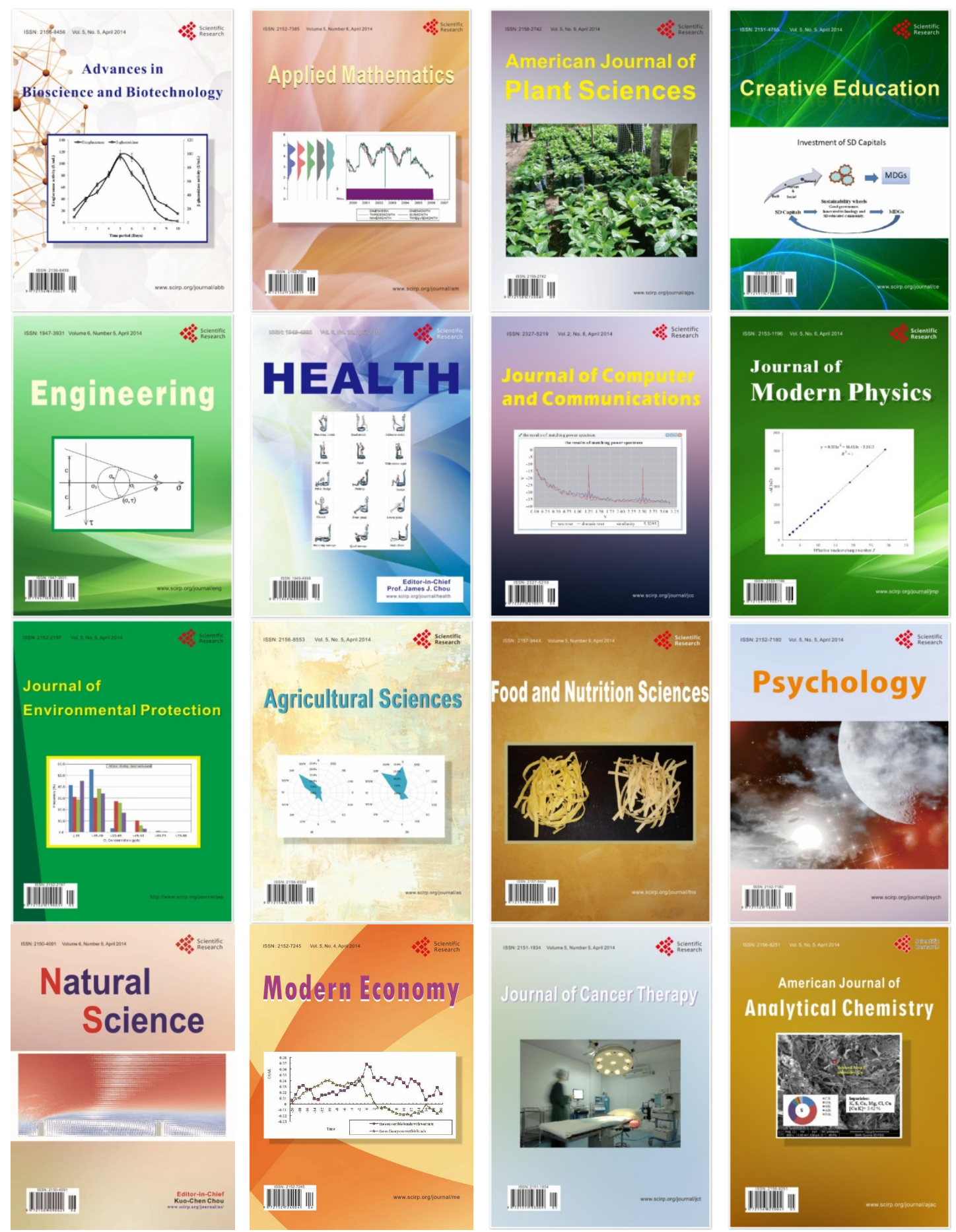